Izv. prof. dr. sc. Damir Primorac ${ }^{1}$

Doc. dr. sc. Maja Buhovac ${ }^{2}$

Nenad Miletić, dipl. iur. ${ }^{3}$

\title{
ISTRAŽIVANJE I DOKAZIVANJE DOPINGA KAO SPORTSKOG DELIKTA S OSVRTOM NA KAZNENOPRAVNI ASPEKT
}

\author{
UDK: $343.57: 796$ \\ $613.83: 796$
}

DOI: $10.31141 / z r p f s .2021 .58 .139 .185$

Pregledni rad

Primljeno: 25. listopada 2020

\begin{abstract}
O dopingu kao kažnjivoj radnji postoje različita teorijska stajališta i mišljenja. Jedni smatraju da se doping treba kažnjavati kaznenopravnim sankcijama, drugi da je dovoljna prekršajnopravna, a treći stegovna sankcija, kako bi se postigla svrha kažnjavanja. U našem pravnom sustavu borba protiv dopinga evoluirala je tako da danas imamo samodoping kao stegovno djelo koje se kažnjava prema pravilima proisteklima iz Svjetskog antidoping kodeksa. S druge strane, zakonodavac propisuje neovlaštenu proizvodnju i promet tvari zabranjenih u sportu kao zasebno kazneno djelo delicta communia, za koje se kažnjava, inter alia, onaj koji omogućava i stavlja na raspolaganje zabranjene tvari sportašu ili koji drugoga navodi na trošenje tih tvari, a to može biti i sam sportaš. Međutim, borba protiv dopinga ne uključuje samo materijalnopravno normiranje nego, štoviše, pitanja načina dokazivanja, otkrivanja i procesuiranja mogućih počinitelja. Stoga autori u ovom radu iznose procesnopravne odredbe kojima je regulirana borba protiv dopinga, što ukazuje na distinkcije koje postoje u pogledu pojedinih počinitelja ovog kaznenog/stegovnog djela. Doping je opasnost modernog svijeta koji se sastoji u prijevarnom postupanju počinitelja uzimanjem zabranjenih tvari radi postizanja vrhunskih rezultata. Pored toga što je nespojiv s etičkim načelima sporta, te što se uzimanjem dopinga može narušiti zdravlje sportaša, doping predstavlja delikt koji je potrebno sankcionirati. Pri tome, ostvariti punitivnu svrhu a ne utjecati negativno na ugled sporta, izazov je koji je stavljen i pred zakonodavca i pred sustav sporta općenito. Stoga borba protiv dopinga mora obuhvaćati sustavnu koordinaciju materijalnopravnih i postupovnih odredbi u cilju zaštite integriteta čistog sporta.
\end{abstract}

Ključne riječi: samodoping, kršenje antidopinških pravila, borba protiv dopinga, istraga, sportski delikt

1 Izv. prof. dr. sc. Damir Primorac, Izvanredni profesor, Sveučilišni odjel za forenzične znanosti Sveučilišta u Splitu, Pravni fakultet Sveučilišta u Mostaru, odvjetnik, damir.primorac@ primorac-partners. com.

2 doc. dr. sc. Maja Buhovac, Docentica, Pravni fakultet Sveučilišta u Mostaru, vanjska suradnica na Kineziološkom fakultetu Sveučilišta u Splitu, maja.buhovac@pf.sum.ba.

3 Nenad Miletić, dipl. iur, Sudac Općinskog građanskog suda u Zagrebu, Ulica grada Vukovara 84, Zagreb, nenad_mltc@yahoo.com. 


\section{UVOD}

Doping je star koliko i sport i sportska natjecanja. Smatra se da potječe od nizozemske ${ }^{4}$ riječi doop što je označavalo opijumski napitak, ali i samo značenje dopinga evoluiralo je u rječniku pa danas označava različite vrste lijekova i drugih tvari koje se koriste za poboljšanu sportsku izvedbu. ${ }^{5} \mathrm{U}$ današnjem kontekstu, riječ „doping” prvi se put pojavila 1879. godine u engleskom jeziku, a označavala je korištenje stimulansa pod čijim utjecajem osoba može dulje raditi. Početkom 1900. godine, riječ se počela koristiti u kontekstu konjičkog sporta i nezakonitih „priprema“ konja za utrke. ${ }^{6}$ Tako je prva doping kontrola zabilježena upravo na konjskim utrkama 1910. godine u Austriji. Naime, zbog velikih dobitaka na klađenju, rezultati konjskih utrka često su se namještali pa je tako 50 posto svih konja bilo pod utjecajem nekog stimulativnog sredstva. I kroz povijest različite biljke korištene su kao doping, što je ovisilo o pojedinoj kulturi. U antičkoj Grčkoj olimpijski natjecatelji provodili su striktne dijete i konzumirali stimulacijske napitke sačinjene od ekstrakta halucinogenih gljiva i biljnih klica. ${ }^{7}$ Da se radi o opasnosti po zdravlje sportaša, svjedoče prvi smrtni slučajevi gdje je uslijed predoziranja stimulansima 1896. godine preminuo engleski biciklist Arthur Linton. ${ }^{8}$ Prva međunarodna sportska organizacija koja je uspostavila zabranu dopinga bila je Međunarodna amaterska atletska federacija 1928. godine. ${ }^{9}$ Međutim, prava era dopinga započela je onoga trenutka kada je predstavljen testosteron u obliku injekcija 1935. godine. Međunarodna biciklistička organizacija (UFI) i Međunarodna nogometna federacija (FIFA) bile su među prvim organizacijama koje su uvele doping testove u svoja svjetska prvenstva 1966. godine. Sljedeće godine dogodila se još jedna tragedija u kojoj je preminuo biciklist na Tour de Franceu ${ }^{10}$ što je bio povod za osnivanje Zdravstvene komisije pri Međunarodnom olimpijskom odboru koja je 1968. godine uvela prvo formalno testiranje na doping na Zimskim olimpijskim igrama u Grenobleu i Ljetnim olimpijskim igrama u Mexico Cityju. ${ }^{11}$

Prema tradicionalnoj definiciji, doping je primjena zabranjenih lijekova ili metoda u svrhu poboljšanja psihofizičke sposobnosti. ${ }^{12}$ Danas definicija dopinga predstavlja kršenje antidopinških pravila koji u prvom redu proizlaze iz Svjetskog antidoping

\footnotetext{
4 Prvi slučaj „,dopinga“ zbio se 1865. godine, kad su nizozemski plivači uhvaćeni u korištenju kofeina. Tepšić, G., Doručak šampiona, Tajne sportske farmakologije, Lexia, Zagreb, 2002., str. 16.

5 Dostupno na https://www.plivazdravlje.hr/aktualno/clanak/8714/Sto-je-doping.html.

6 Muller, R. K., „History of Doping and Doping Control“", u: Hemmerbach, P., Thieme, D. (ur.) Doping in Sports, 2010., str. 2.,

7 Osredkar, J., „,Doping u sportu“. u: Čajevac, R., Heimer, S. (ur.), Medicina sporta, Kineziološki fakultet Sveučilišta u Zagrebu., 2006., str. 399.

8 Tepšić, G., op. cit., str. 16.

9 Pajčić, M., Petković, T., „Doping i kaznenopravna odgovornost“",Zbornik radova Pravnog fakulteta u Splitu, god. 45, 3/2008., str. 552.

10 Englez Tommy Simpson kod kojeg je nakon autopsije utvrđeno da su razlog smrti bili amfetamini. Osredkar, J. op. cit., str. 400.

11 Pajčić, M., Petković, T., op. cit., str. 552.

12 Labar, B., u: Kačer, H. et al., Sportsko pravo, Pravni fakultet Sveučilišta u Splitu, 2018. str. 528.
} 
kodeksa koji donosi Svjetska antidoping agencija (dalje u tekstu: WADA) ${ }^{13}$ Prema Svjetskom antidopinškom kodeksu iz 2015. godine (dalje u tekstu: Kodeks), ${ }^{14}$ to su: a) prisutnost zabranjene tvari ${ }^{15}$ ili njezinih metabolita ili markera u sportaševu uzorku, b) korištenje ili pokušaj korištenja zabranjene tvari ili zabranjene metode, c) izbjegavanje ili odbijanje davanja uzorka ili nepodvrgavanje prikupljanju uzorka, d) propust u podacima o lokaciji, e) krivotvorenje ili pokušaj krivotvorenja bilo kojeg dijela dopinške kontrole, f) posjedovanje zabranjene tvari ili zabranjene metode, g) nedopušteno trgovanje ili pokušaj nedopuštenog trgovanja bilo kojom zabranjenom tvari ili zabranjenom metodom, h) primjena ili pokušaj primjene zabranjene tvari ili zabranjene metode sportašu na natjecanju odnosno primjena ili pokušaj primjene tvari ili metode zabranjene izvan natjecanja sportašu izvan natjecanja, i) sudioništvo, j) zabranjeno udruživanje. ${ }^{16}$

\section{MATERIJALNOPRAVNE ODREDBE O DOPINGU}

\subsection{Osvrt na pravni okvir}

Premda je doping star kao i sam sport i njegovi korijeni sežu još od južnoafričkih plemena, težnja za borbom protiv dopinga nastala je osnivanjem WADA-e. WADA je osnovana u listopadu 1999. godine sa zadatkom da potiče i usmjerava borbu protiv dopinga u sportu na međunarodnoj razini. Nastala je na inicijativu Međunarodnog olimpijskog odbora koji je, posebice nakon natjecanja u biciklizmu u ljeto 1990., odlučio organizirati međunarodnu konferenciju o dopingu. Borba protiv dopinga sustavni je posao koji potječe od WADA-e u obliku kodeksa koji predstavljaju prvu razinu te borbe. Zatim slijede standardi koji određuju listu zabranjenih lijekova, izuzeća od zabrane, način testiranja i uzimanja uzoraka i laboratorijsku analizu. Treću razinu čine pravila koja provode nacionalne antidoping organizacije i međunarodne sportske federacije. Pravila kao produžena ruka kodeksa određuju smjernice i obrasce provedbe dopinške kontrole. Međutim, kodeks kao prva razina borbe omogućuje jedinstveni jezik i način ponašanja o provedbi pravila antidopinga u sportu, te sadrži definiciju dopinga, načela načina dokazivanja dopinga, listu zabranjenih lijekova i metoda, analizu uzoraka, postupak s nalazima, sankcije i žalbe, tajnost i način izvještavanja o rezultatima te moguća ograničenja u provedbi antidopinga.

13 Engl. World Anti Doping Agency, dostupno na https://www.wada-ama.org/en (pristupljeno 6. travnja 2020.)

14 Svjetski antidopinški kodeks 2015., dostupan na https://www.hoo.hr/images/dokumenti/ostalidokumenti/antidoping/Svjetski_antidopin\%C5\%A1ki_kodeks-2015.pdf (pristupljeno 6. travnja 2020.).

15 Popis zabranjenih tvari u sportu u Republici Hrvatskoj za 2020. godinu vidjeti na https://antidopinghzta.hr/za-sportase/popis-zabranjenih-sredstava-sportasi/ (pristupljeno 6. travnja 2020.).

16 Revidirani Svjetski antidoping kodeks 2021., koji treba stupiti na snagu 1. siječnja 2021. godine, dodaje kao kršenje antidopinškog pravila radnje sportaša ili druge osobe usmjerene na zastrašivanje osobe od dobronamjernog izvješćivanja javnosti o kršenju antidopinškog pravila tog sportaša. Točka 2.11. Svjetskog antidoping kodeksa 2021., dostupno na https://www.wada-ama.org/en/resources/thecode/2021-world-anti-doping-code (pristupljeno 6. travnja 2020.). 
Temeljni zadatak u borbi protiv dopinga svakako je trajna edukacija koja uz pravilnu provedbu kontrole dopinga bitno smanjuje pojavnost dopinga. ${ }^{17}$ Prvi Svjetski antidoping kodeks usvojen je 2003. godine, a na snagu je stupio 2004. Njegova izmijenjena i dopunjena verzija stupila je na snagu 2009. Sljedeće izmjene i dopune bile su one od 15. studenoga 2013., te je Kodeks stupio na snagu 1. siječnja 2015. Trenutno je u pripremi revidirana verzija Kodeksa koja treba stupiti na snagu 1. siječnja 2021. Od ostalih međunarodnih pravnih akata za suzbijanje dopinga važna je Europska konvencija protiv dopinga u sportu, donesena u okviru Vijeća Europe u Strasbourgu 1989. godine i njezin dodatni protokol iz Varšave 2002. godine. ${ }^{18}$ Sljedeća je Deklaracija o dopingu u sportu koja je proglašena na Svjetskoj konferenciji o dopingu u sportu u Lausannei 4. veljače 1999. godine. Nakon nje uslijedila je Međunarodna konvencija u borbi protiv dopinga u sportu iz 2005. godine, koja je stupila na snagu 1. veljače 2007. godine. ${ }^{19}$ Svi navedeni akti imaju jednak cilj, a to je promicanje čistog sporta, sprečavanje i suzbijanje dopinga u sportu, te uspostavljanje mjera za ograničavanje dostupnosti i korištenja dopinških sredstava. ${ }^{20}$ Cilj ovog rada jest, uz analizu temeljnih materijalnopravnih odredbi koje egzistiraju i na međunarodnoj i nacionalnoj razini glede borbe protiv dopinga, osobito se osvrnuti na procesnopravna pitanja koja se tiču načina dokazivanja, istrage, kao i postupka utvrđivanja dopinga pred nadležnim tijelima.

\subsection{Materijalnopravni sadržaj dopinga}

Kad je riječ o samom pojmu dopinga, onda vidimo već iz definicije i njegova sadržaja da se radi o aktivnostima koje u sebi sadrže elemente kaznenih djela. Tako analizom kaznenog djela neovlaštene proizvodnje i prometa tvari zabranjenih $u$ sportu $^{21}$ kao počinitelj javlja se osoba koja proizvodi, preradi, prenese, izveze ili uveze, nabavi ili posjeduje, ponudi na prodaju, prodaje ili posreduje u prodaji ili kupnji, ili navodi drugoga na trošenje ili mu da da troši on ili druga osoba zabranjene tvari u sportu. Iz zakonskog opisa bića ovog kaznenog djela, s obzirom na to da se radi o delicta communia, počinitelj može biti i sportaš, primjerice kad bi drugoga navodio da troši zabranjene tvari u sportu što odgovara sadržaju gore opisanog kršenja antidopinškog pravila u vidu sudioništva. Za ovaj oblik kaznenog djela propisana je kazna zatvora do tri godine. Teži oblik ovog kaznenog djela predviđen je u slučaju kad netko ponudi na prodaju, prodaje ili posreduje u prodaji tvari zabranjenih u sportu djetetu ili osobi s težim duševnim smetnjama ili ako to učini u školi ili mjestima koja služe obrazovanju djece te sportskoj aktivnosti ili ako netko

17 Labar, B., op. cit., str. 528-529.

18 Council of Europe Anti-Doping Convention (CETS br. 135) od 16. studenog 1989., dostupno na https://rm.coe.int/CoERMPublicCommonSearchServices/DisplayDCTMContent?documentId=0900001 68007b0e0 (pristupljeno 7. travnja 2020.). Hrvatska je stranka Konvencije od 27. siječnja 1993. godine.

19 Hrvatski sabor je na sjednici održanoj 6. srpnja 2007. godine donio Zakon o potvrđivanju Međunarodne konvencije o borbi protiv dopinga u sportu (NN Međunarodni ugovori 07/2007).

20 Vidjeti više: Pajčić, M., Petković, T., op. cit., str. 557.

21 Glava XIX. Kaznena djela protiv zdravlja ljudi, čl. 191.a KZ-a. 
koristi dijete za počinjenje ovog djela ili to učini službena ili odgovorna osoba. U tom slučaju propisana je kazna zatvora od 6 mjeseci do 5 godina. ${ }^{22}$ Treći oblik djela sastoji se u organiziranju mreže preprodavatelja ili posrednika radi počinjenja ovog djela te zakonodavac predviđa kaznu zatvora od jedne do osam godina. Ako je nekim od navedenih oblika djela prouzročena smrt osobe kojoj su prodane tvari zabranjene u sportu, zakonodavac predviđa kaznu zatvora od tri do petnaest godina, a ako je počinitelj dobrovoljno pridonio otkrivanju djela, sud ga može osloboditi od kazne.

Dakle, vidimo iz analize kršenja antidopinških pravila i ovog kaznenog djela da će za iste radnje sportaši i prateće osoblje ${ }^{23}$ odgovarati za stegovno djelo, što ne sprečava kasnije provođenje kaznenog postupka u slučaju da se radnjama sportaša i pratećeg osoblja ostvare obilježja kaznenog djela iz čl. 191.a KZ-a. U teoriji je bilo prijeporno pitanje koje se pravno dobro povređuje prijevarama s dopingom. To bi u prvom redu bili zdravlje sportaša te imovina, koja su pravna dobra u najvećoj opasnosti od ugroze u praksi. Osim toga, iz ranijih analiza vidljivo je koja kaznena djela mogu nastati kao posljedica korištenja dopinga u sportu. Tu se na popisu navodi širok spektar teških kaznenih djela poput teške tjelesne ozljede, ubojstva, prijevare, primanja i davanja mita i sl. ${ }^{24}$ Stoga ne čudi odluka zakonodavca da osigura kaznenopravnu zaštitu zdravlju sportaša reguliranjem kaznenog djela kojem je cilj suzbiti proizvodnju i promet zabranjenih tvari, jer je to prvi korak u sustavnoj borbi protiv dopinga. Međutim, kada dođu na tržište, zabranjene tvari dospijevaju do sportaša koji za samodopingiranje, za razliku od proizvođača, distributera, preprodavatelja i drugih osoba, ne podliježu kaznenopravnoj sankciji.

Glede kažnjavanja sportaša za samodopingiranje treba istaknuti da je ono prvotno bilo propisano kao prekršaj u Zakonu o sportu (dalje u tekstu: ZS $)^{25}$ iz 2006. godine. ${ }^{26}$ Današnji ZS navodi da sportaši ne smiju uzimati nedopuštena sredstva (doping), niti primjenjivati postupke koji su nedopušteni prema pravilima Hrvatskog olimpijskog odbora, Međunarodnog olimpijskog odbora i WADA-e, kao i to da su obvezni dopustiti obavljanje dopinške kontrole. Dakle, sam ZS ne propisuje ni kaznenu ni prekršajnu odgovornost za doping. Osim toga, Uredbom Vlade Republike Hrvatske 2007. godine osnovana je Hrvatska agencija za borbu protiv dopinga u športu koja je izmjenom ZS-a 2010. godine ukinuta i pripojena novoimenovanom Hrvatskom zavodu za toksikologiju i antidoping (skraceeno: HZTA). Nadležnost HZTA-e temelji se na odredbama Zakona o izmjenama i dopunama ZS-a i Zakona

22 Čl. 191.a st. 2. KZ-a.

23 Prateće osoblje sportaša čine: svaki trener, menadžer, posrednik, timski djelatnik, medicinsko ili pomoćno medicinsko osoblje, roditelj ili bilo koja druga osoba koja radi sa sportašima koji sudjeluju ili se pripremaju za sudjelovanje na sportskom natjecanju. Pravilnik, str. 64.

24 Pajčić, M., Petković, T., op. cit., str. 569. i dalje.

25 Zakon o sportu (NN br. 71/06, 150/08, 124/10, 124/11, 86/12, 94/13, 85/15, 19/16, 98/19).

26 Tako je bila propisana kao prekršaj novčana kazna od 10.000 do 15.000 kuna za fizičku osobu ako uzima nedopuštena sredstva (sportaš) ili ne dopušta obavljanje doping kontrole ili ako (trener, ovlašteni liječnik, i druge osobe u sportu) sportašu daju nedopuštena sredstva ili od sportaša traže ili ga potiču da uzima nedopuštena sredstva. Također se mogla izreći zaštitna mjera zabrane obavljanja sportske djelatnosti fizičkoj osobi u trajanju od jednog mjeseca do jedne godine. Bilo je predviđeno i oduzimanje imovinske koristi ostvarene prekršajem. Pajčić, M., Petković, T., op. cit., str. 586. 
o izmjenama i dopunama Zakona o zdravstvenoj zaštiti (NN br. 139/10). Stupanjem na snagu novog Zakona o zdravstvenoj zaštiti ${ }^{27} 1$. siječnja 2019. godine propisana je stručna i znanstvena djelatnost na područje toksikologije i antidopinga kao jedna od djelatnosti Hrvatskog zavoda za javno zdravstvo (dalje u tekstu: HZJZ). Danom stupanja na snagu ovoga zakona HZJZ preuzeo je sva prava i obveze HZTA-e. ${ }^{28}$ U svrhu suzbijanja dopinga u Republici Hrvatskoj HZJZ donio je Pravilnik za borbu protiv dopinga (dalje u tekstu: Pravilnik). ${ }^{29}$ Kao produžena ruka Kodeksu, Pravilnik je pravni izvor na nacionalnoj razini za borbu protiv dopinga. Pri analizi ovog Pravilnika prvo što uočavamo jest navođenje da antidopinška pravila sadržana u njemu „zasebne su naravi i stoga ne podliježu niti su ograničeni bilo kakvim nacionalnim zahtjevima i pravnim standardima koji vrijede za kaznene ili građanske postupke“.

Za kršenje antidopinških pravila predviđene su sankcije i to a) diskvalifikacija što znači da se sportaševi rezultati na određenom natjecanju ili sportskom događaju proglašavaju nevažećima sa svim posljedicama, uključujući gubitak prava na sve medalje, bodove i nagrade; (b) nepodobnost što znači da se sportašu ili drugoj osobi zbog kršenja antidopinškog pravila na određeno vrijeme zabranjuje sudjelovanje u svim natjecanjima ili u drugim aktivnostima te da mu se uskraćuje financiranje prema Pravilniku, (c) privremena suspenzija (obvezna i neobvezna) što znači da se sportašu ili drugoj osobi privremeno zabranjuje sudjelovanje na svim natjecanjima ili u aktivnostima prije konačne odluke na saslušanju, (d) financijske posljedice što znači financijske sankcije određene za kršenje antidopinškog pravila ili za pokrivanje troškova povezanih s kršenjem antidopinškog pravila; i (e) javna objava ili izvješćivanje što znači objavljivanje ili širenje informacija javnosti ili osobama kojima te informacije do tog trenutka nisu bile dostupne, kao i sankcije za timove. ${ }^{30}$

Dakle, odgovornost za doping predviđena je kao stegovna sankcija, s tim što pojedini elementi kršenja antidopinških pravila mogu predstavljati radnju nekog od kaznenih djela iz KZ-a za koje će se utvrđivati kaznena odgovornost u kaznenom postupku. ${ }^{31}$ Stegovne sankcije primjenjuju se i na sportske timove kad se radi o timskim sportovima, pa ako se utvrdi da je više od dva člana tima u timskom sportu prekršilo antidopinško pravilo, tijelo koje upravlja sportskim događajem izriče

27 Zakon o zdravstvenoj zaštiti (NN br. 100/18, 125/19).

28 Više u predgovoru Pravilnika o borbi protiv dopinga usvojenog od Upravnog vijeća Hrvatskog zavoda za javno zdravstvo 24. siječnja 2019. godine, dostupan na https://www.hoo.hr/images/dokumenti/ antidopinske-aktivnosti/2019/pravilnik-protiv-dopinga-HZJZ-2019.pdf (pristupljeno 7. travnja 2020.).

29 Pravilnik je usvojen od Upravnog vijeća Hrvatskog zavoda za javno zdravstvo 24. siječnja 2019. godine.

30 Poglavlje 10. Pravilnika.

31 WADA je u svom odgovoru na komentare treba li kažnjavati sportaše za doping kao kazneno djelo iz 2015. godine navela kako se ne želi miješati u suvereno pravo bilo koje države da donosi zakone u nacionalnom pravu. Međutim, WADA ne vjeruje da bi doping trebao biti kazneno djelo za sportaše, ali da potiče kažnjavanje onih koji trguju i distribuiraju zabranjene tvari. To je obveza koju su vlade preuzele ratificirajući UNESCO-ovu Međunarodnu konvenciju protiv dopinga u sportu. Vidjeti na https:// www.wada-ama.org/en/media/news/2015-10/wada-statement-on-the-criminalization-of-doping-in-sport (pristupljeno 7. travnja 2020.). 
stegovnu sankciju za tim te pojedinačno sportašu kod kojeg je utvrđeno kršenje. ${ }^{32}$ Međutim, ne smije se zaboraviti uska povezanost dopinga i koruptivnih ${ }^{33}$ kaznenih djela u vidu davanja i primanja mita od strane doping kontrolora, liječnika, trenera i drugih osoba u svrhu manipulacije doping testovima, a sve s ciljem prijevare ${ }^{34} \mathrm{i}$ pribavljanja protupravne imovinske koristi. Manipulacije doping testovima imaju sličan cilj manipulacijama sportskim natjecanjima koje Konvencija Vijeća Europe o manipulaciji športskim natjecanjima propisuje kao kazneno djelo, odnosno poziva države stranke da istu sankcioniraju onda kada manipulacija uključuje prisilu, prijevaru ili korupciju. ${ }^{35} \mathrm{~S}$ druge strane, sportaši su nerijetko i žrtve dopinga, jer njihovim dopingiranjem za postizanje vrhunskih rezultata netko drugi prisvaja protupravnu imovinsku korist.

Kada pogledamo neke poredbenopravne sustave, onda zahtjev za inkriminiranjem dopingiranja sportaša ne bi bila nikakva novost ni u našem pravnom sustavu. Tako je primjerice, u $§ 147$ austrijskog Kaznenog zakona (Strafgesetzbuch) ${ }^{36}$ regulirano kazneno djelo prijevare svakog pojedinca koji je koristio zabranjenu tvar ili metodu u sportu. Kazne ovise o visini novčane nagrade kao posljedice prijevare, a kreću se od novčane kazne do kazne zatvora od 10 godina. ${ }^{37}$

Nadalje, u talijanskom Zakonu o zdravstvenoj zaštiti sportskih aktivnosti i borbu protiv dopinga (Disciplina della tutela sanitaria delle attivita' sportive e della lotta contro il doping $)^{38}$ propisana su tri kaznena djela protiv dopinga. Prva dva kaznena djela odnose se na sportaše i pomoćno osoblje koji nabavljaju, primjenjuju, konzumiraju ili potiču uporabu zabranjenih supstanci ili metoda, s ciljem poboljšanja natjecateljskih učinaka sportaša ili izmjene rezultata doping testa. Propisane su kazna zatvora od tri mjeseca do tri godine i novčana kazna od 2580 do 51.645 eura. ${ }^{39}$ Treće kazneno djelo ima za cilj borbu protiv ilegalnih dobavljača koji trguju

32 Točka 11.2. Pravilnika.

${ }^{33}$ Prevencija dopinga potpomaže suzbijanju drugih, težih oblika kriminaliteta. O teorijama kriminalizacije vidjeti: Gardocki, L., The aspects of theory of criminalization, PWN, Warsaw, 1990., str. 66-68.

${ }^{34}$ O prijevari kao kaznenom djelu koje se postavlja kao cilj činjenja dopinga postavlja se pitanje je li drugi sportaš (ako je protiv njega usmjereno natjecanje) žrtva obmane ili koruptivnog kaznenog djela koje zahtijeva nanošenje određene materijalne štete protivniku. O tome vidjeti kod: Momsen, C., „Sport and doping. The analysis of an antagonistic symbiosis“, u: Emrich, E., Pitsch, W. (eds), Criminal penalties in the fight against doping?, Peter Lang, Frankfurt am Main, Berlin, Bern, Bruxelles, New York, Oxford, Wien, 2011., str. 199.

35 Čl. 15. Konvencije Vijeća Europe o manipulaciji športskim natjecanjima, dostupno na https://sdus. gov.hr/UserDocsImages/dokumenti/Me\% C4\%91 unarodna\%20i\%20EU\%20fondovi/Konvencija\%20 Vije\%C4\%87a\%20Europe $\% 20 \mathrm{o} \% 20$ manipulaciji\%20\%C5\%A1 portskim\%20natjecanjima\%20-\%20HR. pdf (pristupljeno 8. travnja 2020.).

36 Dostupno na https://www.jusline.at/gesetz/stgb (pristupljeno 7. travnja 2020.). Kriminalizaciju dopinga sportaša zagovaraju neki autori i u Velikoj Britaniji smatrajući da bi ona pridonijela odvraćanju sportaša od dopinga i uspostavi čistog sporta. Vidjeti kod: Sumner, C., The spirit of sport: the case for criminalisation of doping in the UK, Springer, 2017.

37 Neke od značajnijih kaznenih postupaka za kaznena djela dopinga u Austriji vidjeti: Murphy, J., Where in the world is doping a crime?, 2013., dostupno na http://parliamentflagpost.blogspot. com/2013/04/where-in-world-is-doping-crime-doping.html (pristupljeno 16. travnja 2020.).

38 Disciplina della tutela sanitaria delle attivita' sportive e della lotta contro il doping, dostupno na http://www.salute.gov.it/imgs/C_17_normativa_652_allegato.pdf (pristupljeno 15. travnja 2020.).

39 Iznosi precizno utvrđeni konverzijom talijanske lire u euro. 
zabranjenim tvarima u sportu za koje je propisana kazna zatvora od dvije do šest godina i novčana kazna od 5164 do 77.468 eura. ${ }^{40}$ I Francuska u svome Zakonu o sportu (Code du sport) $)^{41}$ inkriminira uporabu i korištenje zabranjenih tvari bez opravdanog medicinskog razloga kaznom zatvora od jedne godine ili novčanom kaznom od 3750 eura. Osobe koje sportašima propisuju (liječnici), nude, prodaju zabranjene tvari bez opravdanog medicinskog razloga, kao i osobe koje proizvode, uvoze, izvoze zabranjene tvari u sportu kaznit će se kaznom zatvora od pet godina ili novčanom kaznom od 75.000 eura. Španjolska također inkriminira dopingiranje sportaša, te u svom Zakonu protiv dopinga u sportu (Ley 12/2012, de 21 de junio, contra el Dopaje en el Deporte $)^{42}$ propisuje sankcije suspenzije, lišenja slobode, nemogućnosti pribavljanja savezne licence na vrijeme od dvije do četiri godine $\mathrm{i}$, prema potrebi, novčanu kaznu od 3001 do 12.000 eura. S druge strane, u Zakonu o sprečavanju dopinga u sportu Republike Srbije ${ }^{43}$ propisano je kazneno djelo neovlaštene proizvodnje i prometa doping sredstava za koje je propisana kazna zatvora od tri do dvanaest godina, a za one koji nabavljaju opremu i materijale za koje se zna da su namijenjene za doping propisana je kazna zatvora od šest mjeseci do pet godina. Za razliku od ranije kaznene sankcije za sportaše koji uzimaju doping, sada ovaj zakon propisuje prekršajnopravnu sankciju u obliku novčane kazne od 429 do 1287 eura. ${ }^{44}$ Osim toga, ovaj zakon propisuje kao kazneno djelo i omogućavanje uporabe doping sredstava u čiji krug počinitelja mogu spadati treneri, liječnici i druge osobe, za koje je propisana kazna zatvora od šest mjeseci do pet godina, a u slučaju djela prema maloljetniku, kazna zatvora od dvije do deset godina. Od zemalja iz okruženja, vrijedi spomenuti i Bosnu i Hercegovinu koja ne propisuje kaznene sankcije za dopingiranje sportaša, nego slično kao u Republici Hrvatskoj, za samodopingiranje predviđa disciplinske mjere sukladno Kodeksu, ${ }^{45}$ dok bosanskohercegovački zakonodavac ne propisuje sankcioniranje onih koji proizvode i prometuju s dopingom.

\section{PROCESNOPRAVNE ODREDBE O DOPINGU}

\subsection{Istraga i dokazivanje dopinga}

U dosadašnjim analizama o pitanju dopinga, među pravnim teoretičarima najviše se raspravljalo o tome treba li se samodopingiranje sankcionirati kao prekršaj ili

40 Neki od značajnijih kaznenih postupaka za kaznena djela dopinga u Italiji vidjeti: Murphy, J., op. cit.

${ }^{41}$ Code du sport, dostupan na https://www.legifrance.gouv.fr/affichCode.do?cidTexte=LEGITE XT000006071318 (pristupljeno 15. travnja 2020.).

42 Ley 12/2012, de 21 de junio, contra el Dopaje en el Deporte, dostupan na https://www.boe.es/ buscar/pdf/2012/BOE-A-2012-9010-consolidado.pdf (pristupljeno 15. travnja 2020.).

${ }^{43}$ Zakon o sprečavanju dopinga u sportu Republike Srbije (,Službeni glasnik RS“ br. 11/2014).

44 Iznosi precizno utvrđeni konverzijom srpskog dinara u euro.

45 Vidjeti: Instrukcija za provođenje i primjenu Svjetskog antidoping kodeksa 2015. i Pravilnika za borbu protiv dopinga u sportu u Bosni i Hercegovini, dostupno na https://www.ada.gov.ba/dokumenti/ pravilnici/instrukcija.pdf (pristupljeno 16. travnja 2020.). 
kazneno djelo. Međutim, vrlo zanimljivo je područje istraživanja, dokazivanja te provođenja postupka protiv sportaša kod kojih je utvrđeno postojanje zabranjene tvari u sportu, osobito u odnosu na druge osobe protiv kojih se vodi postupak sukladno odredbama Zakona o kaznenom postupku (dalje u tekstu: ZKP) ${ }^{46}$ zbog kaznenog djela iz čl. 191.a KZ-a. Dakle, protiv sportaša koji prekrši neko antidopinško pravilo provodi se stegovni/disciplinski postupak utvrđen Pravilnikom, dok se u odnosu na kazneno djelo neovlaštene proizvodnje i prometa zabranjenih tvari u sportu provodi kazneni postupak. Iako postoje različita mišljenja o uspješnosti utjecaja kaznenog pravosuđa u borbi protiv dopinga, neka istraživanja pokazuju da se upravo radnjama dokazivanja iz područja kaznenog procesnog prava ostvaruju učinkovitiji rezultati u sveukupnoj borbi protiv dopinga u odnosu na postupke i radnje dokazivanja kakve primjenjuju antidoping organizacije na nacionalnoj i međunarodnoj razini. ${ }^{47}$ U svrhu otkrivanja prekršitelja antidopinških pravila provode se testiranja i istrage u skladu s odredbama Međunarodnog standarda za testiranje i istrage ${ }^{48} \mathrm{i}$ određenim protokolima HZJZ-a. Svrha testiranja jest pribaviti analitičke dokaze o sportaševu poštovanju ili nepoštovanju stroge zabrane prisutnosti ili korištenja zabranjene tvari. Dakle, testiranje kao radnja dokazivanja koristi se samo u svrhu utvrđivanja postojanja ili nepostojanja zabranjenih tvari u organizmu sportaša, dok se u slučaju kršenja ostalih antidopinških pravila provode istrage glede atipičnih nalaza te radi prikupljanja podataka ili dokaza. ${ }^{49}$ Testiranja provodi HZJZ, odnosno Služba za antidoping nadležna za testiranje na natjecanju i izvan natjecanja svih sportaša i može tražiti od bilo kojeg sportaša nad kojim ima nadležnost za testiranje (uključujući sve sportaše koji služe razdoblje nepodobnosti) da daju uzorak bilo kada i bilo gdje. Analogno procesnoj radnji pretrage, ni testiranje se neće obaviti u razdoblju između 23,00 i 6,00 sati, osim u slučaju ozbiljne sumnje da sportaš koristi doping. Prigovor na to je li HZJZ imao opravdan razlog za sumnju za testiranje tijekom tog razdoblja ne služi kao obrana kršenja antidopinškog pravila na osnovi takva testiranja ili pokušaja testiranja. Iako WADA nije agencija koja provodi testiranja, zadržava pravo da ista provodi u iznimnim slučajevima. ${ }^{50}$ Ovlaštenje za testiranje ovisi o vrsti sportskog događaja; ako se radi o međunarodnom natjecanju koji se održavaju u Republici Hrvatskoj prikupljanje uzoraka pokreće i usmjerava

46 Zakon o kaznenom postupku (NN br. 152/08, 76/09, 80/11, 121/11, 91/12, 143/12, 56/13, 145/13, 152/14, 70/17, 126/19, 126/19).

47 Mehanizmi kaznenog pravosuđa profesionalnim biciklistima, trenerima, liječnicima i direktorima biciklističkih timova rezultirali su čišćenjem dopinga u biciklizmu, što nekoliko godina antidoping organizacije i edukacija nisu uspjeli otkriti. O tome vidjeti: McKenzie, C., The use of criminal justice mechanisms to combat doping in sport, Sports Lawyer Association, 2007.

48 Engl. International Standard for Testing and Investigations (ISTI). Prvi ISTI usvojen je 2003. godine, a stupio na snagu 1. siječnja 2004. godine. Zatim je pet puta izmijenjen i dopunjen; prve izmjene i dopune na snazi od 1. siječnja 2009., drugi izmjene i dopune na snazi od 1. siječnja 2011., treće izmjene i dopune na snazi od 1. siječnja 2015., četvrte izmjene i dopune na snazi od siječnja 2017., pete izmjene i dopune na snazi od ožujka 2019. godine te šeste izmjene i dopune na snazi od ožujka 2020. godine. Dostupan na https://www.wada-ama.org/sites/default/files/resources/files/isti_march2019.pdf (pristupljeno 8. travnja 2020.).

49 Točka 5.1. Pravilnika.

50 Točka 5.2. Pravilnika. 
međunarodni savez ili druga međunarodna organizacija koja upravlja sportskim događajem; ako se radi o nacionalnim sportskim događajima koji se održavaju u Hrvatskoj prikupljanje uzoraka pokreće i usmjerava HZJZ. Može se dogoditi da neka organizacija za borbu protiv dopinga koja bi inače bila nadležna za testiranje, ali nije odgovorna za pokretanje i usmjeravanje testiranja na sportskom događaju, želi provesti testiranje sportaša na mjestu natjecanja tijekom sportskog događaja. Tada ona mora prvo kontaktirati HZJZ kako bi dobila dozvolu za provedbu i koordinirala takvo testiranje. U slučaju da navedena organizacija dobije negativan odgovor HZJZ-a, može tražiti dozvolu WADA-e. WADA neće odobriti takvo testiranje prije obavještavanja i konzultacija s HZJZ-om. Odluka WADA-e konačna je i ne podliježe žalbi ${ }^{51} \mathrm{Da}$ bi došlo do testiranja, WADA u dogovoru s međunarodnim savezima i drugim organizacijama za borbu protiv dopinga (HZJZ) usvaja tehnički dokument u sklopu Međunarodnog standarda za testiranje i istrage koji metodom procjene rizika utvrđuje koje će se zabranjene tvari i/ili zabranjene metode najvjerojatnije zloupotrebljavati u pojedinim sportovima i sportskim disciplinama. U tu svrhu HZJZ ima obvezu primjenjivati učinkovit i proporcionalan plan raspodjele testiranja kojim će se prije definirati prioriteti među disciplinama, kategorijama sportaša, tipovima testiranja, tipovima prikupljenih uzoraka i tipovima analize uzoraka. Tako HZJZ određuje skupinu određenu za testiranje koja je sastavljena od sportaša koji su dužni dostavljati podatke o lokaciji na tromjesečnoj bazi te ažurirati te podatke da bi oni u svakom trenutku bili točni i potpuni kao i da sportaš bude dostupan za testiranje na tim lokacijama. ${ }^{52} \mathrm{U}$ protivnom sportaš krši antidopinško pravilo. Da bi se osigurala međusobna suradnja sportskih tijela, HZJZ preko sustava ADAMS ${ }^{53}$ stavlja na raspolaganje popis koji identificira sportaše uključene u njezinu skupinu određenu za testiranje ili prema imenu ili prema jasno definiranim, specifičnim kriterijima te koordinira s međunarodnim savezima identifikaciju takvih sportaša i prikupljanje podataka o njihovoj lokaciji. Podaci o lokaciji sportaša čuvaju se u strogoj tajnosti u svakom trenutku i koriste se isključivo u svrhu njihova testiranja, a nakon što više ne budu relevantni u te svrhe uništavaju se u skladu s Međunarodnim standardom za zaštitu privatnosti i osobnih podataka. ${ }^{54} \mathrm{U}$ slučaju da je sportaš uključen i u skupinu određenu za testiranje svog međunarodnog saveza i u skupinu određenu za testiranje HZJZ-a, HZJZ i međunarodni savez dogovaraju koja će organizacija primati podatke o lokaciji tog sportaša, jer je sportaš dužan dostaviti podatke samo

51 Točka 5.3. Pravilnika.

52 Budući da je cilj dokazivanja dopinga utvrđivanje prisutnosti zabranjenih tvari kod sportaša, dostavljanje informacija o lokaciji sportaša kao neanalitičkom dokazu smatra se spornim. Vidjeti kod: Ioannidis, G., ,,The Application of Criminal Law on Doping Infractions and the 'Whereabouts Information' Rule: State Regulation v Self-Regulation“, The International Sports Law Journal, 2010., str. 14-17.

53 Engl. The Anti Doping Administration and Management System.

54 Engl. International Standard for the Protection of Privacy and Personal Information. Sastavni je dio Kodeksa, prvi put usvojen je 9. svibnja 2009. godine, a stupio na snagu 1. lipnja 2009. Revidirana verzija ISPPPI-ja usvojena je 16. svibnja 2018. godine, a stupila na snagu 1. lipnja 2018. godine. Dostupno na https://www.wada-ama.org/sites/default/files/resources/files/ispppi-_final_-_en.pdf (pristupljeno 9. travnja 2020.). 
jednoj organizaciji. Sportaši će biti obaviješteni prije nego što budu uključeni u skupinu određenu za testiranje i nakon što budu isključeni iz nje. ${ }^{55}$

S obzirom na to da se testiranje provodi na zahtjev HZJZ-a, tako je HZJZ preuzeo ulogu tužitelja u postupku dokazivanja kršenja antidopinških pravila pa je stoga teret dokazivanja na njemu. Dakle, HZJZ se pojavljuje kao nadležno tijelo istrage koje provodi testiranja te u slučaju atipičnih rezultata provodi stegovni postupak protiv sportaša. Pri tome se standard dokazivanja sastoji u postojanju izvjesnosti ${ }^{56}$ da je došlo do kršenja antidopinškog pravila, uzimajući u obzir ozbiljnost iznesenih tvrdnji. Taj standard dokazivanja u svim slučajevima „mora biti iznad obične ravnoteže vjerojatnosti, ali ispod razine utvrđivanja dokaza izvan razumne sumnje " ${ }^{\text {"57 }} \mathrm{i}$ usporediv je sa standardom koji se u većini država primjenjuje u slučajevima nesavjesnoga stručnog ponašanja. S druge strane, ako teret dokazivanja snosi sportaš ili druga osoba koja je navodno prekršila antidopinško pravilo, tada se kao standard dokazivanja uzima ravnoteža vjerojatnosti. Dakle, za dokazivanje korištenja dopinga potrebno je utvrditi razinu vjerojatnosti višu od one koja se zahtijeva za početak istraživanja kaznenih djela. ${ }^{58}$ Pri tome činjenice važne za donošenje odluke o dopingu mogu se utvrditi na bilo koji pouzdan način, uključujući priznanja, što znači da je kao dokaz za kršenje nekog antidopinškog pravila dovoljno da sportaš prizna da je uzimao doping. Osim toga, isto se može utvrditi na temelju vjerodostojnog svjedočenja trećih osoba, pouzdanog dokumentarnog dokaza te pouzdanih laboratorijskih podataka ili zaključaka donesenih na temelju profila niza uzoraka sportaševe krvi ili urina, poput podataka iz biološke putovnice sportaša. Ovo je bitno iz razloga što svi navedeni dokazi mogu poslužiti i u kaznenom postupku kao pravno valjani, dakle nije samo doping test jedini dokaz za utvrđivanje kršenja nekog antidopinškog pravila. Kod utvrđivanja kršenja antidopinških pravila u stegovnom postupku vrijede neka pravila dokazivanja koja proistječu iz Kodeksa. Tako će se analitičke metode ili granične koncentracije koje utječu na odlučivanje, a koje je odobrila WADA nakon konzultacija unutar relevantne znanstvene zajednice i koje su predmetom recenzije ostalih stručnjaka, smatrati znanstveno valjanima. Na pretpostavku znanstvene valjanosti svaki sportaš može uložiti prigovor WADA-i, a također CAS može samoinicijativno obavijestiti WADA-u o takvu prigovoru. ${ }^{59}$ Drugo pravilo dokazivanja sastoji se u pretpostavci da su laboratoriji koje je WADA akreditirala i odobrila proveli analizu

55 Točka 5.6.2. Pravilnika.

56 Izvjesnost bi bila najviši stupanj intenzivnosti svijesti o istini, odnosno podudarnosti predodžbe s činjenicama. Postojala bi kad bi bila isključena svaka mogućnost sumnje. Dika, M., „O standardima utvrđenosti činjenica u parničnom postupku“, Zbornik Pravnog fakulteta Sveučilišta u Rijeci (1991) v. 36, br. 1, 2015., str. 10 .

57 Točka 3.1. Pravilnika.

58 Tako prema našem ZKP-u policija je ovlaštena uhititi osobu za koju postoje osnove sumnje da je počinila kazneno djelo koje se progoni po službenoj dužnosti, a državni odvjetnik je dužan poduzeti kazneni postupak ako postoji osnovana sumnja da je određena osoba počinila kazneno djelo za koje se kazneni postupak pokreće po službenoj dužnosti, a nema zakonskih smetnji za kazneni progon. O osnovama sumnje i osnovanoj sumnji vidjeti kod: Karas, Ž., „Osnove sumnje i osnovana sumnja; zatvoreni krug indicija“, Policijska sigurnost, godina 20., broj 4, Zagreb, 2011., str. 617-624.

59 Točka 3.2.1. Kodeksa, točka 3.2.1. Pravilnika. 
uzorka i postupke zaštite u skladu s Međunarodnim standardom za laboratorije. I ovu pretpostavku sportaš ili druga osoba može pobiti ako utvrdi da je došlo do odstupanja od Međunarodnog standarda za laboratorije koje je u razumnim okvirima moglo uzrokovati nepovoljan laboratorijski nalaz. U slučaju uspjeha dokazivanja istog, HZJZ snosi teret utvrđivanja da to odstupanje nije uzrokovalo nepovoljan laboratorijski nalaz. ${ }^{60}$ Nadalje, odstupanje od bilo kojega drugog međunarodnog standarda ili drugog antidopinškog pravila ili politike definirane Kodeksom ili Pravilnikom koje nije uzrokovalo nepovoljan laboratorijski nalaz ili drugo kršenje antidopinškog pravila neće poništiti valjanost tih dokaza ili rezultata. Ako sportaš ili druga osoba dokaže suprotno, HZJZ snosi teret utvrđivanja da to odstupanje nije uzrokovalo nepovoljan laboratorijski nalaz ili činjeničnu osnovu za kršenje antidopinškog pravila. ${ }^{61}$ Sljedeće pravilo dokazivanja sastoji se u tome da činjenice utvrđene odlukom suda ili nadležnog Stegovnog vijeća koje nisu predmet žalbe predstavljaju neoboriv dokaz protiv sportaša ili druge osobe na koju se ta odluka odnosi, osim ako sportaš ili druga osoba ne dokažu da su tom odlukom prekršena načela pravičnosti. ${ }^{62}$ Posljednje pravilo sastoji se u pravu Stegovnog vijeća da u postupku za odlučivanje o kršenju antidopinškog pravila donese nepovoljnu odluku za sportaša ili drugu osobu za koju se tvrdi da je prekršila antidopinško pravilo na temelju odbijanja sportaša ili druge osobe da se pojavi na saslušanju (osobno ili telefonski prema uputama Stegovnog vijeća) i odgovori na pitanja Stegovnog vijeća ili HZJZ-a koji tvrdi da je antidopinško pravilo prekršeno nakon što je sportašu ili drugoj osobi zahtjev za saslušanje predan u razumnom roku. ${ }^{63}$

Analizom navedenih odredbi koje vrijede za utvrđivanje kršenja antidopinških pravila, možemo zaključiti da se kao standard dokazivanja počinjenja stegovnog djela uzima stupanj vjerojatnosti viši od stupnja vjerojatnosti koji se zahtijeva za kazneni progon. ${ }^{64}$ Samim time otežava se mogućnost utvrđivanja kršenja antidopinških pravila, što negativno utječe na učinkovitu borbu protiv dopinga.

\subsection{Postupak utvrđivanja i dokazivanja dopinga pred sportskim tijelima}

Stegovni postupak protiv sportaša za kršenje antidopinških pravila specifično je uređen. Temeljno pravo koje sportaš ima u ovom postupku jest pravo pravičnog

60 Pri odstupanju od Međunarodnog standarda za laboratorije za koje se pretpostavlja da je u razumnim okvirima moglo uzrokovati nepovoljan laboratorijski nalaz, teret dokazivanja na razini ravnoteže vjerojatnosti snosi sportaš ili druga osoba. Ako sportaš ili druga osoba to učine, teret dokazivanja prebacuje se na HZJZ, koji na razini izvjesnosti mora dokazati Stegovnom vijeću da odstupanje nije uzrokovalo nepovoljan laboratorijski nalaz. Točka 3.2.2. Kodeksa, točka 3.2.2. Pravilnika.

61 Točka 3.2.3. Kodeksa, točka 3.2.3. Pravilnika.

62 Točka 3.2.4. Kodeksa, točka 3.2.4. Pravilnika.

63 Točka 3.2.5. Kodeksa, točka 3.2.5. Pravilnika.

64 O standardu dokazivanja i metodama dokazivanja vidjeti i kod: Zaksaite, S., Radke, H., „The interaction of criminal and disciplinary law in doping-related cases“, The International Sports Law Journal, 2014., str. 115-127. 
saslušanja. ${ }^{65}$ On to pravo ima prije određivanja privremene suspenzije ili u kratkom roku nakon određivanja privremene suspenzije. U svakom trenutku sportaš se može odreći prava na saslušanje. Ako HZJZ pošalje obavijest sportašu ili drugoj osobi da je prekršila antidopinško pravilo, a sportaš se ne odrekne prava na saslušanje, tada se predmet prosljeđuje Stegovnom vijeću HZJZ-a. ${ }^{66}$ Stegovno vijeće mora osigurati da se postupak (saslušanje) zakazuju i završavaju u razumnom roku, te da se provede žurni postupak kad se saslušanje odnosi na neki sportski događaj. Predstavnici WADA-e, Hrvatskog olimpijskog odbora, sportaševa međunarodnog i nacionalnog saveza ili druge osobe mogu nazočiti saslušanju u ulozi promatrača ${ }^{67}$ Nakon provedenog postupka, prvostupanjsku odluku o kršenju antidopinških pravila donosi Stegovno vijeće HZJZ-a. Odluka se dostavlja sportašu te nacionalnom savezu i HZJZ-u i na tu odluku moguće je uložiti žalbu ${ }^{68}$ Žalbenom vijeću HZJZ-a. ${ }^{69}$

Posljednja instanca kojoj je moguće uložiti žalbu na odluku Žalbenog vijeća HZJZ-a jest Sportski arbitražni sud (dalje u tekstu: CAS). ${ }^{70}$ CAS ima konstituiran Odjel za borbu protiv dopinga koji je nadležan za rješavanje pitanja u vezi s dopingom u prvom stupnju ili kao jedina instanca. ${ }^{71}$ Postupci pred CAS-om u vezi s dopingom provode se de novo, što znači da CAS nije vezan za prethodne odluke donesene na nacionalnoj ili međunarodnoj razini. Sve zainteresirane strane uključene u borbu protiv dopinga (WADA, HZJZ i druge organizacije) uz odobrenje sportaša mogu zatražiti jedno saslušanje i to direktno pred CAS-om čime se doprinosi ekonomičnosti postupka, ali isto tako treba imati na umu da su odluke CAS-a konačne i obvezujuće. Rok za podnošenje žalbe CAS-u iznosi 21 dan od dana primitka odluke. Žalbu CAS-u mogu podnijeti sportaš ili druga osoba na koju se odnosi odluka koja je predmet žalbe; druga strana u predmetu u kojem

65 O ,minimalnim zahtjevima“ pravičnog saslušanja (koji između ostalog uključuju pravovremeno saslušanje, pravo na podnošenje dokaza itd.) vidjeti: Soek, J., The strict liability principle and the human rights of athletes in doping cases, T.M.C. Asser Press, The Hague, 2006., str. 361.

66 Stegovno vijeće sastoji se od devet članova koje imenuje Upravno vijeće HZJZ-a, s tim da se imenuju predsjednik i dva dopredsjednika uz uvjet da su pravnici s najmanje pet godina radnog iskustva u pravosuđu. Predsjednik Stegovnog vijeća ili, u njegovoj odsutnosti, dopredsjednik, imenuje tri člana vijeća u pojedinom predmetu koje sačinjava predsjednik ili dopredsjednik koji njime predsjedava, jedan liječnik i jedan sportaš ili sportski djelatnik. Cl. 3. Poslovnika Stegovnog i Žalbenog vijeća, dostupan na https://www.hzjz.hr/wp-content/uploads/2019/03/06022019_poslovnik-stegovnog-i-zalbenog-vijeca.pdf (pristupljeno 19. travnja 2020.).

67 Točka 8.2.3. Pravilnika.

68 Ako se ne uloži žalba na odluku Žalbenog vijeća, tada će odluka Žalbenog vijeća za kršenje antidopinškog pravila biti javno objavljena, ili ako je donesena odluka da nije prekršeno antidopinško pravilo, odluka će se objaviti javno samo uz suglasnost sportaša ili druge osobe na koju se odluka odnosi. Isto se odnosi i na odluku Stegovnog vijeća. Točka 13.2.2.3.3. Pravilnika.

69 Žalbeno vijeće sastoji se od 5 članova, 3 koja imenuje HZJZ te 2 člana nominira Hrvatski olimpijski odbor. Žalbeno vijeće u pojedinom predmetu ima pet članova, a sačinjavaju ga predsjednik, jedan liječnik, jedan sportaš ili sportski djelatnik, te dva člana nominirana od strane Hrvatskog olimpijskog odbora. Čl. 4. Poslovnika Stegovnog i Žalbenog vijeća.

70 Engl. Court of Arbitration for Sport. CAS je utemeljen 1984. sa sjedištem u Lausannei, Švicarska. Nadležan je za rješavanje sporova u oblasti sporta, a time i pitanja dopinga o kojima može odlučivati u prvom stupnju ili kao jedina instanca. CAS ima urede u Sydneyju i u New Yorku, a službeni jezici su engleski i francuski. Više na https://www.tas-cas.org/en/index.html (pristupljeno 10. travnja 2020.).

71 S20 b. Code of Sport-related Arbitration, dostupno na https://www.tas-cas.org/fileadmin/user upload/CAS_Code_2019_EN_.pdf (pristupljeno 11. travnja 2020.). 
je donesena odluka; nadležni međunarodni savez; HZJZ, Međunarodni olimpijski odbor odnosno Međunarodni paraolimpijski odbor ako bi odluka mogla imati veze s Olimpijskim igrama ili Paraolimpijskim igrama, uključujući odluke koje utječu na zadovoljavanje uvjeta za nastupanje na Olimpijskim igrama ili Paraolimpijskim igrama i WADA. ${ }^{72}$ U slučaju privremene suspenzije jedina je osoba koja se može žaliti na tu odluku sportaš ili druga osoba kojoj je određena privremena suspenzija. Jedna od iznimnih situacija kada se WADA može izravno žaliti CAS-u jest slučaj da HZJZ nije pravovremeno donio odluku o tome je li prekršen Pravilnik jer se u tom slučaju smatra kao da je donio odluku da nije prekršen Pravilnik. Žalba CAS-u može se podnijeti i u postupcima za utvrđivanje terapijskih izuzeća. ${ }^{73}$ Naime, odluku o terapijskom izuzeću donosi HZJZ koji obavještava sportaša. To terapijsko izuzeće može vrijediti samo za nacionalnu razinu, te sportaš koji se natječe na međunarodnoj razini mora zatražiti terapijsko izuzeće od međunarodnog saveza. U slučaju da međunarodni savez ne odobri terapijsko izuzeće koje sportaš ima na nacionalnoj razini, tada sportaš i HZJZ mogu uputiti predmet na razmatranje WADA-i te se mogu žaliti CAS-u. Dakle, prikazani postupak utvrđivanja dopingiranja sportaša pretpostavlja provođenje stegovnog postupka. No, to ne sprečava pravosudna tijela na ovlaštenje da se provede kazneni postupak u slučaju kad se kroz stegovni postupak utvrdi da se radi o takvim kršenjima koja u sebi sadrže elemente prijevare, korupcije i sl. Osobito bi to bilo potrebno kad je u dopingiranje sportaša uključen širi krug osoba, ili pak kad bi se sportaš namjerno dopingirao s ciljem prijevare. ${ }^{74}$

Odluku koju je CAS donio u prvom stupnju moguće je preispitati pred Žalbenim odjelom CAS-a. ${ }^{75}$ Jedini pravni lijek protiv odluke Žalbenog odjela CAS-a (ako to klauzulom ili ugovorom nije isključeno) jest tužba za poništenje pravorijeka Vrhovnom sudu Švicarske. ${ }^{76}$ Tužba ovom sudu može se podnijeti u slučaju da se arbitražni sud pogrešno proglasio nadležnim, odnosno nenadležnim, u slučaju da je arbitražni sud odlučio preko granice zahtjeva ili je propustio odlučiti o nekom od zahtjeva, ako su prekršena bitna procesna pravila, te ako je pravorijek suprotan pravnom poretku. Vrhovni sud Švicarske odluku ${ }^{77}$ donosi na temelju činjenica koje su ustanovljene u prethodnom postupku, nema novog saslušanja stranaka, niti prezentiranja novih dokaza. ${ }^{78}$

72 Točka 13.2.3. Pravilnika.

73 Terapijsko izuzeće znači da se neće smatrati kršenjem antidopinškog pravila prisutnost zabranjenih tvari ako su one odobrene kao terapijsko izuzeće sukladno Međunarodnom standardu za terapijska izuzeća. Točka 4.4. Pravilnika.

74 O dvosmjernosti istraga, kaznenih i stegovnih, u slučaju manipulacija sportskim natjecanjima vidjeti kod: Van Rompuy, B., „Effective sanctioning of match-fixing: the need for a two-track approach“, ICSS J 1(3), 2013., str. 68-72.

75 R47 Code of Sports-related Arbitration.

76 Art 77 (Zakona o Vrhovnom sudu) Loi du 17 juin 2005 sur le Tribunal federal, stupio na snagu 1. siječnja 2007., dostupan na https://www.admin.ch/opc/fr/classified-compilation/20010204/index.html (pristupljeno 19. travnja 2020.).

77 Više o nadležnosti Vrhovnog suda Švicarske u sportskim sporovima vidjeti: Puljko, V., ,Arbitraža i medijacija u sportu“, Strani pravni život, 2017., str. 68-69.

78 Poznat je predmet Pehstein u kojem je švicarski Vrhovni sud odlučivao o dopingu. Ibid., str. 70. 


\section{PRAKTIČNI UČINCI BORBE PROTIV DOPINGA}

U prethodnim poglavljima ovog rada predstavljen je materijalnopravni i procesnopravni okvir borbe protiv dopinga. Kad je riječ o praktičnim učincima te borbe, onda možemo govoriti o mjerama koje izriče HZJZ za doping ili pak o predmetima proslijeđenih CAS-u na odlučivanje. U sljedećem dijelu rada prikazat ćemo i statističke pokazatelje glede kaznenog djela proizvođača, distributera, preprodavatelja i drugih osoba koje se bave neovlaštenom proizvodnjom i prometom tvari zabranjenih u sportu. O dopingu i njegovoj opasnosti po ugled sporta, zdravlje sportaša i sport općenito upozorava i Interpol u svojim dvotjednim izvješćima. Stoga će ovo poglavlje biti posvećeno prikazu nekih praktičnih primjera različitih instanci koje su odlučivale o dopingu.

\subsection{Mjere HZJZ-a}

Služba za antidoping HZJZ-a objavila je na web-stranici prvo Godišnje izvješće za 2019. kojim se, sukladno međunarodnim obvezama iz Kodeksa i drugih relevantnih propisa, osigurava transparentnost informacija kao jedan od ključnih elemenata antidopinške borbe. S obzirom na to da je Pravilnik usvojen u siječnju 2019. godine, te su svakako pohvalne aktivnosti nadležne Službe za antidoping HZJZ-a u pogledu pravovremenog informiranja i transparentnosti podataka o mjerama koje su u proteklom razdoblju izrečene. Tako se u ovom izvješću navodi da je u protekloj godini bilo provedeno 612 dopinških kontrola ${ }^{79} \mathrm{u}$ nacionalnom programu, od čega 312 na natjecanju, a 300 izvan natjecanja. Provedeno je 63 analiza iz krvi, a 549 analiza iz urina kao biološkog materijala, 25 analiza krvi za biološku putovnicu. Provedeno je 88 analiza na egzogenu primjenu tvari koje stimuliraju eritropoezu, 62 analize na egzogenu primjenu čimbenika otpuštanja hormona rasta i 61 analiza na egzogenu primjenu hormona rasta. U sklopu međunarodne suradnje provedeno je 118 dopinških kontrola, od čega 115 na natjecanju, a 3 izvan natjecanja. Provedeno je 117 analiza iz urina kao biološkog materijala i 1 analiza krvi. Kad je riječ o propustima u podacima o lokaciji sportaša u 2019. godini zabilježeno je osam propuštenih testiranja. U sklopu postupanja rezultatima, održano je deset sjednica Stegovnog vijeća HZJZ-a. U tablici ispod nalazi se prikaz sjednica Stegovnog vijeća u 2019. godini i mjere koje su izrečene sportašima. ${ }^{80}$

79 O doping kontrolama, pozitivnim slučajevima i ekonomskim posljedicama provođenja dopinških kontrola vidjeti kod: Dvorak, J., Saugy, M., Pitsiladis, Y. P., ,Challenges and threats to implementing the fight against doping in sport“", Br J Sports Med, 2014., str. 807-809.

80 Godišnje izvješće Službe za antidoping za 2019., dostupno na https://antidoping-hzta.hr/wpcontent/uploads/2020/03/GODI\%C5\%A0NJE-IZVJE\%C5\%A0\%C4\%86E-SLU\%C5\%BDBE-ZAANTIDOPING_2019.pdf (pristupljeno 11. travnja 2020.). 
Tabelarni prikaz zasjedanja Stegovnog vijeća

\begin{tabular}{|c|c|c|c|c|c|c|}
\hline $\begin{array}{l}\text { Datum } \\
\text { zasjedanja }\end{array}$ & Sport & $\begin{array}{l}\text { Prekršit } \\
\text { elj }\end{array}$ & $\begin{array}{l}\text { Vrsta i skupina } \\
\text { tvari s Popisa }\end{array}$ & Stegovna mjera & $\begin{array}{l}\text { Odredba } \\
\text { Pravilnika } \\
\text { koja je } \\
\text { prekršena }\end{array}$ & Opaska \\
\hline $\begin{array}{l}08.02 .2019 . \\
\text { SP 09/18 }\end{array}$ & odbojka & sportaš & $\begin{array}{l}\text { karboksi THC } \\
\text { (S8) }\end{array}$ & $\begin{array}{c}8 \text { mjeseci } \\
\text { nepodobnosti }\end{array}$ & 2.1 & $\begin{array}{l}\text { postupak iz } \\
2018 .\end{array}$ \\
\hline $\begin{array}{l}14.02 .2019 \\
\text { SP 08/18 }\end{array}$ & rukomet & sportaš & $\begin{array}{l}\text { oktopamin } \\
\text { (S6.b) }\end{array}$ & $\begin{array}{c}1 \text { godina } \\
\text { nepodobnosti }\end{array}$ & 2.1 & $\begin{array}{l}\text { postupak iz } \\
\text { 2018. / zalba } \\
\text { HZJZ-a }\end{array}$ \\
\hline $\begin{array}{l}14.02 .2019 . \\
\text { SP } 10 / 18\end{array}$ & košarka & sportaš & terbutalin (S.3) & $\begin{array}{c}4 \text { mjeseca } \\
\text { nepodobnosti }\end{array}$ & 2.1 & $\begin{array}{l}\text { postupak iz } \\
2018 \text {. }\end{array}$ \\
\hline $\begin{array}{l}23.04 .2019 \\
\text { SP 01/19 }\end{array}$ & rukomet & sportaš & $\begin{array}{l}\text { kokain i } \\
\text { njegovi } \\
\text { metaboliti } \\
\text { (S6.a) }\end{array}$ & $\begin{array}{l}2 \text { godine } \\
\text { nepodobnosti }\end{array}$ & 2.1 & \\
\hline $\begin{array}{l}24.04 .2019 \\
\text { SP 02/19 }\end{array}$ & $\begin{array}{l}\text { obaranje } \\
\text { ruku }\end{array}$ & sportaš & $\begin{array}{l}\text { metandienon } \\
\text { (Sl.a) }\end{array}$ & $\begin{array}{l}4 \text { godine } \\
\text { nepodobnosti }\end{array}$ & 2.1 & \\
\hline $\begin{array}{l}13.05 .2019 \\
\text { SP 03/19 }\end{array}$ & $\begin{array}{l}\text { powerliftin } \\
\mathrm{g}\end{array}$ & sportaš & $\begin{array}{l}\text { trenbolon } \\
\text { (Sl.a), } \\
\text { norandrosteron } \\
\text { (Sl.b) }\end{array}$ & $\begin{array}{l}4 \text { godine } \\
\text { nepodobnosti }\end{array}$ & 2.1 & \\
\hline $\begin{array}{l}23.05 .2019 \\
\text { SP 04/19 } \\
\end{array}$ & plivanje & sportaš & $\begin{array}{l}\text { karboksi THC } \\
\text { (S8) }\end{array}$ & $\begin{array}{l}8 \text { mjeseci } \\
\text { nepodobnosti }\end{array}$ & 2.1 & \\
\hline $\begin{array}{l}30.05 .2019 \\
\text { SP 05/19 }\end{array}$ & $\begin{array}{l}\text { hokej na } \\
\text { ledu }\end{array}$ & sportaš & & $\begin{array}{l}\text { nije odobreno } \\
\text { skracivanje } \\
\text { razdoblja } \\
\text { nepodobnosti }\end{array}$ & 2.5 & $\begin{array}{l}\text { postupak iz } \\
2017 . / 4 \\
\text { godine } \\
\text { nepodobnosti }\end{array}$ \\
\hline $\begin{array}{l}11.09 .2019 \\
\text { SP 06/19 }\end{array}$ & $\begin{array}{l}\text { bodybuildi } \\
\text { ng }\end{array}$ & sportaš & & $\begin{array}{l}4 \text { godine } \\
\text { nepodobnosti }\end{array}$ & 2.3 & $\begin{array}{l}02.07 .2019 . \\
\text { odgođeno } \\
\text { ročišste SV }\end{array}$ \\
\hline $\begin{array}{l}04.07 .2019 . \\
/ 12.09 .2019 \\
\text { SP 07/19 }\end{array}$ & $\begin{array}{l}\text { bodybuildi } \\
\text { ng }\end{array}$ & sportaš & & $\begin{array}{l}2 \text { godine } \\
\text { nepodobnosti }\end{array}$ & 2.3 & $\begin{array}{l}\text { sjednica SV } \\
\text { održana u } \\
\text { dva dijela / } \\
\text { zalba HZJZ- } \\
\text { a }\end{array}$ \\
\hline
\end{tabular}

Izvor: Godišnje izvješće Službe za antidoping za 2019.

Dakle, iz tabelarnog je prikaza vidljivo kako je Stegovno vijeće u 2019. godini zasjedalo 10 puta zbog kršenja antidopinških pravila, dok je Žalbeno vijeće zasjedalo dva puta. U tablici ispod prikazana su zasjedanja Žalbenog vijeća te odluke po žalbi. 
Tabelarni prikaz zasjedanja Žalbenog vijeća

\begin{tabular}{|l|l|l|l|l|l|l|}
\hline $\begin{array}{l}\text { Datum } \\
\text { zasjedanja }\end{array}$ & Sport & Prekršitelj & $\begin{array}{l}\text { Vrsta i } \\
\text { skupina tvari s } \\
\text { Popisa }\end{array}$ & Stegovna mjera & $\begin{array}{l}\text { Odredba } \\
\text { Pravilnika } \\
\text { koja je } \\
\text { prekršena }\end{array}$ & Opaska \\
\hline $\begin{array}{l}\text { 15.05.2019. } \\
\text { ŽP 01/19 }\end{array}$ & rukomet & sportaš & $\begin{array}{l}\text { oktopamin } \\
\text { (S6.b) }\end{array}$ & $\begin{array}{l}\text { preinačena } \\
\text { odluka SV, } \\
\text { određuje se 2 } \\
\text { godine } \\
\text { nepodobnosti }\end{array}$ & 2.1 & SP 08/18 \\
\hline $\begin{array}{l}\text { 09.12.2019. } \\
\text { ŽP 02/19 }\end{array}$ & bodybuilding & sportaš & & $\begin{array}{l}\text { preinačena } \\
\text { odluka SV, } \\
\text { određuje se 4 } \\
\text { godine } \\
\text { nepodobnosti }\end{array}$ & 2.3 & SP 07/19 \\
\hline
\end{tabular}

Izvor: Godišnje izvješće Službe za antidoping za 2019. godinu

\subsection{Noviji predmeti pred CAS-om}

a) CAS 2019/A/6148 WADA protiv kineskog plivača Sun Yanga i Fédération Internationale de Natation (FINA)

U ovom predmetu radi se o kršenju antidopinških pravila u vidu izbjegavanja ili odbijanja davanja uzorka ili nepodvrgavanja prikupljanju uzorka te krivotvorenju ili pokušaju krivotvorenja bilo kojeg dijela dopinške kontrole. Radi se o postupku u kojem je WADA podnijela žalbu CAS-u protiv kineskog olimpijskog i svjetskog prvaka u plivanju Sun Yanga. Naime, organizacija ovlaštena za testiranje izvan natjecanja u sastavu od 4 osobe stigla je na adresu sportaša u razdoblju između 22,00 i 23,00 sata kako je sam inicirao. Pri tome, prema tvrdnjama sportaša i njegova liječnika, samo jedna od kontrolora imala je akreditaciju i certifikat za ovlaštenje pri uzimanju uzoraka. Iako je sportaš surađivao prilikom uzimanja uzoraka, nakon što ga je jedan od kontrolora nekoliko puta fotografirao, sportaš je odmah nazvao svoga liječnika i svoju pratnju te je njegov zaštitar uništio staklene boce u kojima su bili uzorci s opravdanjem da su uzorke uzimale neovlaštene osobe. WADA je 14. veljače 2019. podnijela žalbu CAS-u protiv sportaša i FINA-e za kršenje navedenih antidopinških pravila. Nakon provedenog postupka, CAS je donio odluku 28. veljače 2020. godine o osmogodišnjoj nepodobnosti ovog sportaša, nakon čega je sportaš najavio žalbu Vrhovnom sudu Švicarske. ${ }^{81}$

\section{b) CAS 2019/A/6110 Liam Cameron protiv UK Anti-Doping Limited (UKAD)}

$\mathrm{U}$ ovom predmetu radi se o kršenju antidopinškog pravila prisutnosti zabranjene tvari koja je utvrđena u organizmu boksača Liama Camerona u postupku pred

81 Predmet dostupan na https://www.tas-cas.org/fileadmin/user_upload/CAS_Award_6148_website. pdf (pristupljeno 11. travnja 2020.). 
nacionalnom organizacijom za borbu protiv dopinga. Sportaš nije osporavao uzimanje zabranjenih tvari koje su se sastojale u metabolitima kokaina, s naglaskom da to nije učinio namjerno, ali je osporavao visinu sankcije koja mu je izrečena, a to je 4 godine nepodobnosti. Žalbu je podnio CAS-u na kojem je saslušanje zakazano 23. listopada 2019., nakon čega je CAS odbio žalbu sportaša o smanjenju sankcije. Inače razdoblje nepodobnosti za ovog sportaša započelo je 25. svibnja 2018. godine, a završava 24. svibnja 2022. godine. ${ }^{82}$

\section{c) CAS u predmetu Hiromasa Fujimorija protiv FINA-e}

Radi se o predmetu u kojem je CAS svoju odluku po žalbi sportaša Hiromase Fujimorija, japanskog plivača, donio 6. ožujka 2020. godine, kojom je odbijena žalba sportaša. Naime, tijekom provođenja dopinške kontrole na natjecanju utvrđena je prisutnost zabranjene tvari kod sportaša te mu je FINA izrekla sankciju u obliku nepodobnosti na razdoblje od dvije godine. U žalbi CAS-u sportaš je zatražio da se sankcija svede na ukor ili razdoblje nepodobnosti između 3 i 6 mjeseci, ili najdulje 12 mjeseci, tvrdeći da je pozitivan rezultat proizašao iz gutanja kontaminirane kuglice riže dan prije testa. ${ }^{83}$

\subsection{Aktivnosti Interpola u borbi protiv dopinga}

U okviru Interpola postoji projekt koji uključuje sustavnu analizu svakog poznatog slučaja dopinga, posebno proizvoda (vrste, slike, trgovačke marke, porijekla i lanca nabave i sl.). U sklopu tog projekta pokreću se istrage koje zahtijevaju međunarodnu suradnju, a cilj im je otkrivanje kriminalnih organizacija koje se bave trgovinom drogama za korištenje u sportu. Tako je Interpol sudjelovao u operaciji „Augeas“ koja se sastoji u globalnoj istrazi navodne međunarodne prijevare za korupciju u koju su upleteni sportski dužnosnici i sportaši osumnjičeni za zataškavanje dopinga u atletici. Predvođena Francuskom i nakon izvještaja WADA-e, ova istraga iz 2015. godine dovela je do objavljivanja crvene obavijesti ${ }^{84}$ protiv jednog od sudionika $u$ ovom slučaju. Također, u travnju 2016. Interpol je surađivao s američkom Upravom za provođenje droga kako bi prekinuli ilegalnu proizvodnju i distribuciju lijekova za povećanje učinkovitosti pri sportskim natjecanjima. Operacija je rezultirala milijunima zaplijenjenih bočica, pilula i ampula, više od 30 osoba je uhićeno, a četiri sofisticirana tajna laboratorija su demontirana.

82 Predmet dostupan na https://www.tas-cas.org/fileadmin/user_upload/Award_6110_internet.pdf (pristupljeno 11. travnja 2020.).

83 Predmet dostupan na https://www.tas-cas.org/fileadmin/user_upload/CAS_Media_Release_6541. pdf (pristupljeno 11. travnja 2020.).

84 Interpol izdaje crvene, narančaste i ljubičaste obavijesti kao upozorenje zemljama na tražene osobe, ozbiljne prijetnje i način rada. Na primjer, 2015. godine Interpol je izdao narančastu obavijest kako bi upozorili vlasti na dinitrofenol (DNP), nezakonitu i potencijalno smrtonosnu drogu koja se koristi kao pomoć u dijeti i izgradnji tijela. Iste godine objavljeno je nekoliko ljubičastih obavijesti kojima se policija obavještava o novim metodama koje se koriste za prikrivanje lijekova za povećanje sportskog učinka kako bi neprimijećeno prošli kroz carinsku kontrolu. O obavijestima Interpola vidjeti https://www.interpol.int/ How-we-work/Notices/About-Notices (pristupljeno 11. travnja 2020.). 
Osim provedenih operacija, Interpol na dvotjednoj bazi donosi izvješća pod nazivom Integrity in sport u kojem se navode sve provedene istrage vezane za korupciju u sportu i svim kažnjivim radnjama. Među njima su i neki od posljednjih skandala koji su vezani za kaznena djela u vezi s dopingom. Tako se u izvješću Interpola za 3. - 16. ožujka $2020 .{ }^{85}$ navodi kako je u Americi pokrenuta istraga protiv jedanaest trenera jahanja, sedam veterinara te devet dobavljača i distributera lijekova koji su uključeni u dopingiranje trkačkih konja diljem Amerike i svijeta, gdje su konji dopingirani takvim tvarima koje su im uzrokovale srčane probleme, prekomjernu napetost koja je dovela do prijeloma nogu te u nekim slučajevima smrt. Navodi se kako se radi o najdalekosežnijem dopingiranju konja u povijesti američkog Ministarstva pravosuđa koje je izjednačeno sa zlostavljanjem. ${ }^{86} \mathrm{U}$ jednom drugom Interpolovom izvješću ${ }^{87}$ doznajemo o povezanosti korupcije i dopinga u koju su uključeni Međunarodna federacija za dizanje utega i njezin dugogodišnji šef Tamas Ajan. Optuženi su za uspostavljanje „kulture“ korupcije „, i prikrivanja dopinga tijekom natjecanja u kojoj su istaknuti dizači utega rijetko bili podvrgnuti testovima, dok su neki doping kontrolori navodno uzimali novac kako bi manipulirali uzorcima urina" ${ }^{88}$ Sličan je primjer kenijskog atletskog trenera Michaela Roticha koji je suspendiran na 10 godina zbog upletenosti u korupciju vezanu za doping. ${ }^{89}$ Javnost je posebno zatresla i afera s ruskom zabranom natjecanja na Olimpijskim igrama u Tokiju 2020. zbog optužbi da su njezini najviši atletski dužnosnici nadzirali zataškavanje dopinških prekršaja skakača u vis koji je dobio nagradu da osvoji zlato na tom natjecanju. Istraga je rezultirala četverogodišnjom zabranom Rusije na velikim svjetskim natjecanjima. Posebno je važno istaknuti zajedničku akciju Interpola, Europola, Zajedničkog istraživačkog centra, Europskog ureda za borbu protiv prijevara (OLAF), te WADA-e u kojoj je zaplijenjeno više od 3,8 milijuna zabranjenih tvari u sportu i krivotvorenih lijekova u 33 države, raskrinkano 17 skupina organiziranog kriminaliteta, demontirano 9 podzemnih laboratorija, osumnjičene 234 osobe, te otvoreno 839 sudskih predmeta. Radi se o najvećoj akciji ove vrste ikad, predvođene talijanskim karabinjerima. Utvrđeno je da počinitelji koriste različite metode za promet i stavljanje na raspolaganje zabranjenih tvari, pa se tako navodi da veletrgovci uvoze ogromne količine steroida kako bi prehranili ilegalno tržište; neprofesionalni sportaši, biciklisti i bodybuilderi kupuju male količine steroida, uglavnom iz Azije ili istočne Europe kako bi ih prevezli u teretane; sve se više koriste društvene mreže za oglašavanje, promociju i prodaju anaboličkih proizvoda; male organizirane kriminalne skupine ulažu u ilegalne laboratorije i prodaju droge; pojavljuje se kontinuirani rast neovlaštenih

85 Interpol, Integrity in Sport, Bi-weekly Bulletin, 3-16 March 2020.

86 Više o tome vidjeti na https://www.nbcnews.com/news/us-news/horse-racing-trainersveterinarians-charged-nationwide-doping-scandal-n1153126 (pristup 13. travnja 2020.).

87 Interpol, Integrity in Sport, Bi-weekly Bulletin, 17 December 2019 - 16 January 2020.

${ }_{88}$ Više o tome vidjeti na http://www.rfi.fr/en/wires/20200105-corruption-doping-cover-internationalweightlifting-federation-report-0 (pristupljeno 13. travnja 2020.).

89 Vidjeti više na https://www.foxnews.com/sports/kenyas-olympic-track-coach-banned-10-yearsfor-corruption (pristupljeno 13. travnja 2020.). 
online ljekarni, također na dark $w e b u^{90}$ te se uočava veće korištenje kreditnih kartica i kripto valuta za obavljanje transakcija. ${ }^{11}$ Osim korupcije s dopingom, kao sredstva počinjenja korupcije pojavljuju se i sami sportaši. Tako je svijet zatresao skandal s bivšim vodećim američkim atletskim trenerom koji je suspendiran na četiri godine, a kojeg se optužuje da je sportaše koristio kao laboratorijske životinje. ${ }^{2}$ Dakle, vidimo da je borba protiv dopinga znatno složenija od samog utvrđivanja prisutnosti zabranjene tvari u organizmu sportaša, te zahtijeva aktivnosti svih institucija $u$ koordiniranim istragama protiv kaznenih djela u koja je uključen i doping.

\subsection{Statistički prikaz praktičnih učinaka kaznenih postupaka protiv počinitelja kaznenih djela u vezi s dopingom u Republici Hrvatskoj}

Na kraju ovog rada želimo ukratko prikazati statističke pokazatelje borbe protiv dopinga koji proizlaze iz provedenih kaznenih postupaka protiv osoba koje se bave neovlaštenom proizvodnjom i prometom zabranjenih tvari u sportu. Tu se prije svega radi o onima koji proizvode, prevoze, uvoze, izvoze, stavljaju na raspolaganje, čine dostupnim, prodaju ili nude na prodaju, te posreduju u prodaji, ali i onima koji navode drugoga na trošenje tvari zabranjenih u sportu.

\begin{tabular}{|c|c|c|c|}
\hline Godina & Prijavljene osobe & Optužene osobe & Osuđene osobe \\
\hline 2018. & $\begin{array}{l}\text { Čl. 191.a st. } 1 .-\mathbf{1 4} \\
\text { Čl. 191.a st. } 2 . \mathbf{- ~} 8\end{array}$ & $\begin{array}{l}\text { Čl. 191.a st. } 1 .-\mathbf{1 4} \\
\text { Čl. 191.a st. } 2 . \mathbf{- 1}\end{array}$ & $\begin{array}{l}\text { Čl. 191.a st. 1. - } 13 \\
\text { Čl. 191.a st. 2. - } 0\end{array}$ \\
\hline 2017. & $\begin{array}{l}\text { Čl. 191.a st. } 1 .-\mathbf{1 7} \\
\text { Čl. 191.a st. } 2 .-\mathbf{6}\end{array}$ & $\begin{array}{l}\text { Čl. 191.a st. } 1 .-\mathbf{1 2} \\
\text { Čl. 191.a st. 2. - } 0\end{array}$ & $\begin{array}{l}\text { Čl. 191.a st. 1. - } 11 \\
\text { Čl. 191.a st. 2. - } 0\end{array}$ \\
\hline 2016. & $\begin{array}{l}\text { Čl. 191.a st. } 1 .-20 \\
\text { Čl. 191.a st. } 2 .-\mathbf{1 0}\end{array}$ & $\begin{array}{l}\text { Čl. 191.a st. } 1 .-\mathbf{1 4} \\
\text { Čl. 191.a st. 2. - } 0\end{array}$ & $\begin{array}{l}\text { Čl. 191.a st. 1. - } 14 \\
\text { Čl. 191.a st. 2. - } 0\end{array}$ \\
\hline 2015. & $\begin{array}{l}\text { Čl. 191.a st. } 1 .-27 \\
\text { Čl. 191.a st. } 2 .-6 \\
\text { Čl. 191.a. st. } 3 .-1\end{array}$ & $\begin{array}{l}\check{C} 1.191 . \text { a st. } 1 .-\mathbf{1 1} \\
\text { Čl. 191.a st. } 2 . \mathbf{- 0} \\
\text { Čl. 191.a. st. } 3 .-\mathbf{0}\end{array}$ & $\begin{array}{l}\check{C} l .191 . a \text { st. } 1 . \mathbf{- 1 1} \\
\text { Čl. 191.a st. 2. -0 } \\
\text { Čl. 191.a. st. 3. } \mathbf{- 0}\end{array}$ \\
\hline
\end{tabular}

Izradili autori

90 Dark web jest dio interneta koji se sastoji od stranica koje postoje samo na kriptiranoj mreži, koje nije moguće pronaći na tražilicama poput Googlea i na koje se ne može doći klasičnim browserima poput Chromea ili Sarafija. Više na: https://marketingorbis.com/2020/01/27/sto-je-dark-web-i-kako-doci-donjega/ (pristupljeno 13. travnja 2020.).

91 Europol, dostupno na https://www.europol.europa.eu/newsroom/news/keeping-sport-safe-andfair-38-million-doping-substances-and-fake-medicines-seized-worldwide (pristupljeno 13 travnja 2020.)

92 Vidjeti više na: https://www.index.hr/sport/clanak/koristio-je-sportase-kao-laboratorijskezivotinje/2120957.aspx (pristupljeno 16. travnja 2020.). 
Od navedenih postupaka osobito je važno spomenuti i one gdje se kao počinitelji javljaju mlađe punoljetne osobe. U 2018. godini takve su optužene i osuđene dvije osobe, u 2017. godini tri osobe, te u 2016. godini dvije osobe..$^{3}$

\section{V.ZAKLJUČAK}

Borba protiv dopinga u Republici Hrvatskoj regulirana je kroz pravila koja proizlaze iz Svjetskog antidoping kodeksa. Za kršenje antidopinških pravila provodi se stegovni postupak pred Stegovnim vijećem Hrvatskog zavoda za javno zdravstvo. U svrhu otkrivanja prekršitelja antidopinških pravila provode se testiranja i istrage. Testiranje kao radnja dokazivanja koristi se samo u svrhu utvrđivanja postojanja ili nepostojanja zabranjenih tvari u organizmu sportaša, dok se u slučaju kršenja ostalih antidopinških pravila provode istrage glede atipičnih nalaza te radi prikupljanja podataka ili dokaza. Pri tome, standard dokazivanja koji se sastoji u postojanju izvjesnosti da je došlo do kršenja nekog od antidopinških pravila zahtijeva viši stupanj vjerojatnosti od onog koji se zahtijeva za kazneni progon prema našem ZKP-u. Cjelokupni postupak borbe protiv dopinga prikazan u radu rezultat je procjene našeg zakonodavca da se doping smatra stegovnim djelom, pa se posljedično sportašu izriču stegovne sankcije. Međutim, ukoliko se utvrdi da su sportaš ili prateće osobe sportaša svojim radnjama ostvarili obilježja kaznenog djela glede neovlaštene proizvodnje i prometa tvari zabranjenih u sportu, nema nikakve zapreke da oni odgovaraju i za kazneno djelo iz čl. 191.a KZ-a. Naime, radi se o općem kaznenom djelu (delicta communia), što znači da ga može počiniti svatko, kako sportaš ili prateće osoblje sportaša, tako i netko treći. Stoga možemo reći da je zakonodavac napravio iskorak u sankcioniranju svih koji na bilo koji način omogućavaju dostupnost i korištenje zabranjenih tvari u sportu što svakako pogoduje borbi protiv dopinga i zaštiti integriteta čistog sporta. Kada je riječ o kažnjavanju samodopinga, ono i dalje ostaje kao stegovno djelo, za razliku od nekih poredbenih sustava (Italija, Španjolska, Francuska) gdje je samodoping propisan kao kazneno djelo. Međutim, u radu su prikazani i neki primjeri gdje se sportaši pojavljuju kao žrtve dopingiranja te se postavlja pitanje za neke daljnje rasprave je li pravedno kažnjavanje sportaša za samodoping kao rezultat prisile od strane njegova pratećeg osoblja, ili ako ga se dovodi u zabludu o svojstvu tih tvari. Osim toga, i iz aktivnosti Interpola vidljivo je da ni samodopingiranje sportaša ne isključuje aktivnosti tijela kaznenog progona usmjerene na borbu protiv drugih teških oblika kriminaliteta poput prijevare, korupcije, pranja novca i sl. U svakom slučaju, borba protiv dopinga znatno je složenija od samog utvrđivanja prisutnosti zabranjene tvari u organizmu sportaša, te zahtijeva aktivnosti svih institucija u koordiniranim istragama protiv i stegovnih i kaznenih djela u koja je uključen i doping.

93 Podaci dostupni na https://www.dzs.hr/ (pristupljeno 13. travnja 2020.). 


\section{LITERATURA}

1. CAS 2019/A/6110 Liam Cameron protiv UK Anti-Doping Limited (UKAD) dostupan na https://www.tas-cas.org/fileadmin/user_upload/Award_6110_internet.pdf.

2. CAS 2019/A/6148 WADA protiv kineskog plivača Sun Yanga i Fédération Internationale de Natation (FINA), dostupan na https://www.tas-cas.org/fileadmin/ user_upload/CAS_Award_6148_website.pdf.

3. CAS u predmetu Hiromasa Fujimorija protiv FINA-e, dostupan na https://www.tascas.org/fileadmin/user_upload/CAS_Media_Release_6541.pdf.

4. Code du sport, dostupan na https://www.legifrance.gouv.fr/affichCode.do?cidTexte $=$ LEGITEXT000006071318.

5. Code of Sport-related Arbitration, dostupno na https://www.tas-cas.org/fileadmin/ user_upload/CAS_Code_2019_EN_.pdf.

6. Council of Europe Anti-Doping Convention, (CETS br. 135) od 16. studenog 1989. dostupno na https://rm.coe.int/CoERMPublicCommonSearchServices/DisplayDCT MContent?documentId=090000168007b0e0.

7. Dika, M., „O standardima utvrđenosti činjenica u parničnom postupku“, Zbornik Pravnog fakulteta Sveučilišta u Rijeci, (1991) v. 36, br. 1, 2015.

8. Disciplina della tutela sanitaria delle attivita' sportive e della lotta contro il doping, dostupno na http://www.salute.gov.it/imgs/C_17_normativa_652_allegato.pdf.

9. Dvorak, J., Saugy, M., Pitsiladis, Y. P., „Challenges and threats to implementing the fight against doping in sport“, Br J Sports Med, 2014.

10. Godišnje izvješće Službe za antidoping za 2019., dostupno na https://antidoping-hzta. hr/wp-content/uploads/2020/03/GODI\%C5\%A0NJE-IZVJE\%C5\%A0\%C4\%86ESLU\%C5\%BDBE-ZA-ANTIDOPING_2019.pdf.

11. Gardocki, L., The aspects of theory of criminalization, PWN, Warsaw, 1990.

12. Instrukcija za provođenje i primjenu Svjetskog antidoping kodeksa 2015. i Pravilnika za borbu protiv dopinga u sportu u Bosni i Hercegovini, dostupno na https://www. ada.gov.ba/dokumenti/pravilnici/instrukcija.pdf.

13. Interpol, Integrity in Sport, Bi-weekly Bulletin, 17 December 2019 - 16 January 2020.

14. Interpol, Integrity in Sport, Bi-weekly Bulletin, 3-16 March 2020.

15. Ioannidis, G., „The Application of Criminal Law on Doping Infractions and the 'Whereabouts Information' Rule: State Regulation v Self-Regulation“, The International Sports Law Journal, 2010.

16. Kačer, H. et al., Sportsko pravo, Pravni fakultet Sveučilišta u Splitu, 2018.

17. Karas, Ž., „Osnove sumnje i osnovana sumnja; zatvoreni krug indicija“, Policijska sigurnost, godina 20., broj 4, Zagreb, 2011.

18. Kazneni zakon (NN br. 125/11, 144/12, 56/15, 61/15, 101/17, 118/18, 126/19).

19. Konvencija Vijeća Europe o manipulaciji športskim natjecanjima, dostupno na https:// sdus.gov.hr/UserDocsImages/dokumenti/Me\%C4\%91 unarodna\%20i\%20EU\%20 fondovi/Konvencija\%20Vije\%C4\%87a\%20Europe\%20o\%20manipulaciji\%20 $\%$ C5\%A1portskim\%20natjecanjima\%20-\%20HR.pdf. 
20. Ley 12/2012, de 21 de junio, contra el Dopaje en el Deporte, dostupan na https:// www.boe.es/buscar/pdf/2012/BOE-A-2012-9010-consolidado.pdf.

21. McKenzie, C., The use of criminal justice mechanisms to combat doping in sport, Sports Lawyer Association, 2007.

22. Loi du 17 juin 2005 sur le Tribunal federal, dostupan na https://www.admin.ch/opc/ fr/classified-compilation/20010204/index.html.

23. Momsen, C., „Sport and doping. The analysis of an antagonistic symbiosis“, u: Emrich, E., Pitsch, W. (eds), Criminal penalties in the fight against doping?, Peter Lang, Frankfurt am Main, Berlin, Bern, Bruxelles, New York, Oxford, Wien, 2011.

24. Muller, R. K., „History of Doping and Doping Control“”, u: Hemmerbach, P., Thieme, D. (ur.), Doping in Sports, 2010.

25. Murphy, J., Where in the world is doping a crime?, 2013., dostupno na http:// parliamentflagpost.blogspot.com/2013/04/where-in-world-is-doping-crime-doping. html

26. Osredkar, J., „Doping u sportu“, u: Čajevac, R., Heimer, S. (ur.), Medicina sporta, Kineziološki fakultet Sveučilišta u Zagrebu., 2006.

27. Pajčić, M., Petković, T., „Doping i kaznenopravna odgovornost“, Zbornik radova Pravnog fakulteta u Splitu, god. 45, 3/2008.

28. Popis zabranjenih tvari u sportu u Republici Hrvatskoj za 2020. godinu vidjeti na https://antidoping-hzta.hr/za-sportase/popis-zabranjenih-sredstava-sportasi/.

29. Poslovnik Stegovnog i Žalbenog vijeća, dostupan na https://www.hzjz.hr/wp-content/ uploads/2019/03/06022019_poslovnik-stegovnog-i-zalbenog-vijeca.pdf.

30. Pravilnik za borbu protiv dopinga, dostupan na https:/www.hoo.hr/images/ dokumenti/antidopinske-aktivnosti/2019/pravilnik-protiv-dopinga-HZJZ-2019.pdf.

31. Puljko, V., „Arbitraža i medijacija u sportu“, Strani pravni život, 2017.

32. Soek, J., The strict liability principle and the human rights of athletes in doping cases, T.M.C. Asser Press, The Hague, 2006.

33. Strafgesetzbuch, dostupan na https://www.jusline.at/gesetz/stgb.

34. Sumner, C., The spirit of sport: the case for criminalisation of doping in the UK, Springer, 2017.

35. Svjetski antidoping kodeks 2021., dostupno na https://www.wada-ama.org/en/ resources/the-code/2021-world-anti-doping-code.

36. Svjetski antidopinški kodeks 2015., dostupan na https://www.hoo.hr/images/ dokumenti/ostali-dokumenti/antidoping/Svjetski_antidopin\%C5\% A1ki_ kodeks-2015.pdf.

37. Tepšić, G., Doručak šampiona, Tajne sportske farmakologije, Lexia, Zagreb, 2002.

38. Van Rompuy, B., „Effective sanctioning of match-fixing: the need for a two-track approach“, ICSS J 1(3), 2013.

39. Zakon o kaznenom postupku (NN br. 152/08, 76/09, 80/11, 121/11, 91/12, 143/12, $56 / 13,145 / 13,152 / 14,70 / 17,126 / 19,126 / 19)$.

40. Zakon o sportu (NN br. 71/06, 150/08, 124/10, 124/11, 86/12, 94/13, 85/15, 19/16, 98/19). 
41. Zakonu o sprečavanju dopinga u sportu Republike Srbije („Službeni glasnik RS“ br. 11/2014).

42. Zakon o zdravstvenoj zaštiti (NN br. 100/18, 125/19).

43. Zaksaite, S., Radke, H., ,The interaction of criminal and disciplinary law in dopingrelated cases“, The International Sports Law Journal, 2014.

44. ama.org/sites/default/files/resources/files/ispppi-_final_-_en.pdf

45. https://www.wada-ama.org/en/media/news/2015-10/wada-statement-on-thecriminalization-of-doping-in-sport

46. http://www.rfi.fr/en/wires/20200105-corruption-doping-cover-internationalweightlifting-federation-report-0

47. https://www.dzs.hr/

48. https://www.europol.europa.eu/newsroom/news/keeping-sport-safe-and-fair-38million-doping-substances-and-fake-medicines-seized-worldwide

49. https://www.foxnews.com/sports/kenyas-olympic-track-coach-banned-10-years-forcorruption

50. https://www.interpol.int/How-we-work/Notices/About-Notices

51. https://www.nbcnews.com/news/us-news/horse-racing-trainers-veterinarianscharged-nationwide-doping-scandal-n1153126

52. https://www.plivazdravlje.hr/aktualno/clanak/8714/Sto-je-doping.html

53. https://www.tas-cas.org/en/index.html

54. https://www.wada-ama.org/en

55. https://www.wada-ama.org/sites/default/files/resources/files/isti_march2019.pdf

56. https://www.index.hr/sport/clanak/koristio-je-sportase-kao-laboratorijskezivotinje/2120957.aspx

57. https://marketingorbis.com/2020/01/27/sto-je-dark-web-i-kako-doci-do-njega/ 


\section{INVESTIGATION AND VERIFICATION OF CRIMINAL ASPECTS OF DOPING AS A CRIME IN SPORT LAW}

There are different theoretical views and opinions on doping as a punitive act. Some believe that doping should be punished by criminal sanctions, others that a misdemeanor law is sufficient, the and third is a disciplinary sanction, to achieve the purpose of punishment. In our legal system, the fight against doping has evolved so that today we have self-doping as a disciplinary offense punishable under the rules of the World Anti-Doping Code. On the other hand, the legislator prescribes the unauthorized production and marketing of substances banned in sport as a separate offense of delicta communia, punishable, inter alia, by one who, permits and makes prohibited substances available to the athlete or who induces another to consume those substances, which may be himself athlete. However, the fight against doping involves not only substantive legal standardization but, moreover, questions of how to prove, detect and prosecute possible perpetrators. Therefore, the authors of this paper present procedural provisions governing the fight against doping, which points to the differences that exist with respect to the perpetrators of this criminal / disciplinary offense. Doping is a danger in the modern world, consisting in the fraudulent treatment of perpetrators by taking illicit substances in order to achieve superior results. In addition to being incompatible with the ethical principles of sport, and doping can impair the health of athletes, doping is a tort that needs to be sanctioned. In doing so, to pursue a punitive purpose and not adversely affect the reputation of sport is a challenge that has been put before both the legislature and the sport system in general. Therefore, the fight against doping must include the systematic coordination of substantive and procedural provisions in order to safeguard the integrity of pure sport.

Key words: self-doping, anti-doping rule violation, fight against doping, investigation, sport tort 